\title{
A cserénfai kísérlet - két év múlva
}

A tanulmány szerzői 2003-ban és 2004-ben egy kísérlet során vizsgálták az IKT terjedésének hatásait egy kis faluban, Cserénfán. Számítógépeket és internet-hozzáférést biztosítottak kiválasztott helyi családok számára, azt vizsgálva, hogy milyen előnyei és hátrányai vannak az információs technológia intézményi és kapcsolatháló-alapú terjedésének. Mivel a faluban működött teleház, ennek forgalmát kívánták összevetni a baráti-szomszédsági hozzáférés gyakoriságával és természetével. Vizsgálták továbbá az IKT terjedésének a település lakosságának életkörülményeire közvetve gyakorolt társadalmi hatásait is, a közérzetüket jelző indikátorok alapján. 2005 októberében viszszatértek a faluba és interjúk segítségével felmérték alanyaik életének és az internetről alkotott véleményének alakulását az eltelt idő alatt.

Kulcsszavak: internet, falu, hátrányos helyzetü település, az információs technológia társadalmi hatásai, digitális szakadék, közösségi informatika, teleház

\section{Szerzői információ:}

Eranus Eliza

Szociológus, $\mathrm{PhD}$-tanulmányait végzi a Budapesti Corvinus Egyetemen.

Lengyel György

Szociológus, a Budapesti Corvinus Egyetem oktatója.

E-mail: gyorgy.lengyel@uni-corvinus.hu

Siklós Viktória

Szociológus, doktori tanulmányokat folytat a Budapesti Corvinus Egyetemen.

Így hivatkozzon erre a cikkre:

Eranus Eliza, Lengyel György, Siklós Viktória. „A cserénfai kísérlet - két év múlva”.

Információs Társadalom VI, 2. szám (2006): 109-122.

$\Longrightarrow \quad$ https://dx.doi.org/10.22503/inftars.VI.2006.2.11

A folyóiratban közölt müvek

a Creative Commons Nevezd meg! - Ne add el! - Így add tovább! 4.0 
Eranus Eliza - Lengyel György - Siklós Viktória

\section{A cserénfai kísérlet - két év múlva}

\section{Előzmények}

A számítógépek és a számítógépes tudás terjedését elôször 2001-ben kezdtük el vizsgálni a településen. 2001 és 2003 között empirikus kutatássorozatot végeztünk a kaposvári kistérségben. Ennek keretében mintegy 40 strukturált mélyinterjút készítettünk, valamint kérdőíves módszerrel megvizsgáltunk egy 800 fốs felnốtt és egy 110 fôs általános iskolás gyermek mintát. A panelvizsgálat során két ízben kerestük fel a kérdôíves felvételek résztvevôit, így jutottunk el egyebek közt Cserénfára is. Cserénfa Kaposvártól 12 km-re délkeletre található, lélekszáma 257 fő. A községben egy élelmiszerüzlet és egy kocsma van. A település lakosságának mintegy ötöde fiatal, harmada nyugdíjas, és körülbelül 6\%-a roma származású. A munkalehetôségek igen korlátozottak, a lakosság pesszimistán ítélte meg a munkalehetôségeket. A faluból hiányoznak a közintézmények, a gyerekek a szomszédos településre járnak iskolába. Mindezek mellett az utóbbi években a dinamikus fejlesztés jeleivel is találkozunk. Szobrot, játszóteret avattak, falugondnokot neveztek ki, létesült egy viszonylag jól felszerelt teleház is, ami a nyugdíjasklubbal és a könyvtárral együtt az önkormányzat épületében múködött, továbbá 2005-ben egy összkomfortos vendégházat is kialakítottak egy meglévố önkormányzati épületben. Kutatásaink során világossá vált, hogy a számítógépek, az internet, illetve a számítógépes tudás terjedése itt nem tekinthetố tipikus innovációdiffúziós folyamatnak, mivel a lakossági számítógépes ellátottság alakulásában és a számítógépes ismeretek megszerzésében az oktatás és az önkormányzati közigazgatás intézményei játsszák a főszerepet (Láng-Letenyei-Siklós, 2003; EranusLáng-Letenyei, 2003).

Másfelól az izolációra és a korlátozott kommunikációra vet fényt, hogy e kis faluban is szinte megoldhatatlan feladatnak látszott egyértelmú választ kapni arra az egyszerûnek túnő kérdésre, hogy kinek volt először számítógépe a faluban. Akiról mások ezt gondolták, az úgy tudta, hogy másnak elóbb volt, amaz megint egy harmadikra mutatott, és így tovább. Ilyen feltételek között izgalmas kihívásnak látszott összevetni, hogy kikhez ér el az internet a teleház révén és kikhez magánházakban, ahol egymástól tanulják az emberek a számítógép és a világháló használatát. Azt is vizsgálni kívántuk, hogy milyen másodlagos társadalmi hatásai lehetnek az internet kétféle használatának.

Tapasztalatainkról összefoglaló jelent meg a Jel-kép 2004/2. számában, és részletesebb beszámoló olvasható A cserénfai kísérlet címú múhelytanulmány-kötetben (szerk. Lengyel Gy. - Siklós V., Budapest, BKÁE, 2004). Ezek a közvetlen tapasztalatokat rögzítették. Ezért úgy gondoltuk, hogy hasznos lehet, ha két évvel a kísérlet beindítása után újabb terepmunkával térképezzük fel az azóta bekövetkezett változásokat. Eredményeinkról a jelen írásban számolunk be. 


\section{A kísérletről}

A kísérlet elókészítố fázisában a nagy érdeklődésre való tekintettel két kezdő és egy haladó számítógép-kezelési és internethasználati tanfolyamot szerveztünk (Futó, 2003; Füleki, 2003). Ezt követôen négy számítógépet helyeztünk el, és kilenc helyen internet-hozzáférési lehetôséget teremtettünk olyan családoknál, akik késznek mutatkoztak arra, hogy a kísérlet során együttmúködjenek és tapasztalataikról rendszeresen beszámoljanak. Ennek segítségével lehetôségünk nyílt megvizsgálni, hogy a magánházakba telepített számítógépek és internet-hozzáférési lehetôségek másként szolgálhatják-e az információs technológia terjedését, mint a teleházprogram. Arra voltunk kíváncsiak, hogy milyen társadalmi csoportokhoz ér el az informatikai tudás és a számítógép iránti igény a teleház, illetve a magánszemélyek révén (bốvebben lásd Lengyel et al., 2004; Eranus-Letenyei, 2004).

A kísérlet rövid távú hatásait mérlegelve azt láttuk, hogy ahogy nôtt az internetforgalom a magánházaknál, úgy csökkent a teleházaknál, és fordítva. Egy kis településen tehát a két megoldás funkcionális alternatívát kínálhat. Továbbá - bár a vizsgált időszakban az internet „látogatottsága” mind a teleház, mind pedig a magánházak esetében csökkent - összességében többen és többször használták a számítógépet magánházaknál, mint a teleházban.
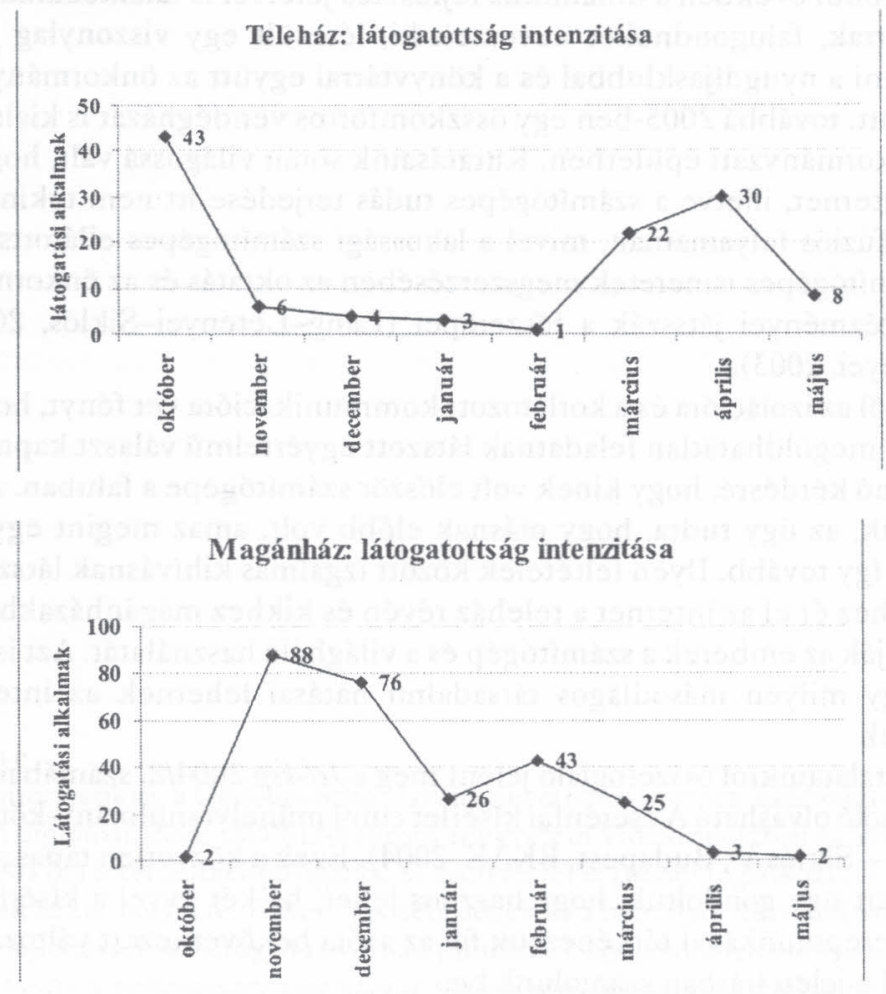

Forrás: A teleház által vezetett statisztika, illetve saját adatgyưjtés, 2003-2004. 
A teleház funkciójának vizsgálatakor azt találtuk, hogy a felnôttek számára a teleház önmagában nem elég motiváló tényezố ahhoz, hogy teljesen laikusként bemenjenek, és kipróbálják a számítógépet vagy internetet. A teleház akkor tud igazán hatni az egyes személyekre, ha van egy tanfolyam vagy egy meghatározó személy, vagy valamilyen figyelemfelkeltô akció, ami vagy aki ténylegesen olyan irányba mozdítja az embereket, hogy többször visszajöjjenek a teleházba, használják a gépeket, vagy vegyenek maguknak otthonra. Az is világossá vált, hogy ennek a korcsoportnak komoly lehetôséget kínál az, ha „házhoz jön” az internet. Az idősebb emberekre inkább az jellemző, hogy még ha saját bevallásuk szerint nagyon érdekli is óket az internet, akkor sem mennek be „csak úgy” internetezni a teleházba. Ennek több oka lehet: a teleházban a gyerekek és a fiatalok uralják a terepet, akiktól nem szívesen vennék el a géphasználat lehetôségét, vagy nem szívesen mutatkoznának elő́ttük járatlannak, esetleg csak zavarja óket a közeg, nem szívesen fordítanak erre pénzt, nem szimpatizálnak a vezetókkel, vagy egyszerủen nem szívesen mozdulnak ki otthonról (bốvebben lásd Siklós, 2004). Ugyanakkor a standard szolgáltatás, az elófizetés kedvezóbb volta, a rendszergazda jelenléte és a tanácsadás lehetôsége a teleház esetében elốnyösebb megoldásnak mutatkozik. Mind a teleház, mind pedig a kihelyezés esetében a szórakozási és kommunikációs célú internetes tevékenységi formák voltak dominánsak, a kihelyezés esetében azonban az információszerzố és erôforrás-bôvítoó tevékenységek is nagyobb teret kaptak, különösen a képzettebb, rutinosabb felhasználók esetében. Ez összefüggésben lehet azzal is, hogy a kihelyezés esetében a családtagok közül a felnóttek is gépközelbe kerültek.

A kísérleti szakasz végén azt a következtetést vontuk le, hogy az olyan települések és városrészek esetében, amelyekben nincs teleház vagy más közösségi internetelérési mód, a kihelyezés alapvetően jó eszköz lehet.

Ez elsôsorban az információs technológiai eszközöknek olyan társadalmi csoportokhoz való célzott eljuttatására lehet alkalmas, amelyek egyébként nem jutnának számítógéphez. Ilyenek az idôsek, az alacsony jövedelmúek, a helyhez kötöttek, a marginális helyzetúek, a romák, a pályakezdók stb. Ugyanakkor indokoltnak tartottuk a hasonló kihelyezési programok hosszabb távú múködtetését, hiszen rövid távon nehéz kezelni az olyan problémákat, mint amilyeneket az internetszolgáltató adminisztrációs hibái, a váratlan események (például betegség, elköltözés) vagy a telefon-összeköttetés akadozásai okozhatnak. A kísérlet során a szolgáltatóval való egyeztetés igen sok adminisztratív nehézséggel, félreértéssel és bosszússággal járt, amelyek között az utolsó az volt, hogy másfél évvel a program lezárása után, 2005 karácsonyán is küldtek ki téves fizetési felszólítást a kísérlet egyes résztvevóinek.

Továbbá arra következtettünk, hogy hatékonyságuk növelése érdekében mind a kihelyezési programot, mind pedig a teleházprogramot össze kell kapcsolni tanfolyamokkal, a tartalomszolgáltatás javításával, folyamatos technikai asszisztenciával és segítségnyújtással. A tanfolyamokon súlyt kell helyezni a tartalomkeresési lehetôségek elsajátítására. Ezenkívül fontosnak bizonyult a széles sávú internetkapcsolat megvalósítása a magánházaknál való kihelyezés esetében is. 


\section{Két év múlva: összesített eredmények}

A számítógépes kísérletet követôen akár a kihelyezésnek, akár a számítógépes „írástudás” terjedésének a társadalmi hatásait illetốen csak a közvetlen tapasztalatokat tudtuk értékelni. Ezért, mint említettük, két évvel a cserénfai kísérlet beindítása után újabb terepmunkát végeztünk a településen azzal a céllal, hogy a kísérlet hosszabb távú hatásait vizsgáljuk meg.

Fốként az érdekelt minket, hogy miként befolyásolta a kísérlet az információs technológia terjedését, milyen összefüggés van a teleház és a kihelyezés között, és milyen változások történtek a faluban.

\subsection{Miként befolyásolta a számítógépes kihelyezés a számítógépek} és az internet terjedését?

Elôző kutatásaink során megfogalmaztuk, hogy bár a számítógépek terjedése többé-kevésbé követi az $\mathrm{S}$ görbe alakját, mégsem tekinthetố egy innovációdiffúziós jelenségnek, hiszen a számítógépek terjedését nagymértékben befolyásolják az intézmények (Eranus-Láng-Letenyei, 2003).

Az alábbi ábrán látható, hogy a kumulált görbe némi töréssel veszi fel a hagyományos $\mathrm{S}$ görbe kezdeti szakaszának mintáját. A számítógépek kihelyezésének időszakában (2003-2004) először stagnálás következett be, amit növekedés követett. Sajnos az eredményeink nem havi lebontásban szerepelnek, az interjúk alapján azonban kiderült, hogy a kísérletünk időszakában csak két új számítógép került a településre, míg három számítógép „elhagyta” a falut. Viszont a direkt összefüggés még ezután sem egyértelmú, inkább arról lehet szó, hogy a terjedési folyamat lassúbb növekedési fázisba került. Ezután két forgatókönyv lehetséges: vagy gyorsabb növekedéssel eléri a görbe a szaturációs szintet, majd elkezd stagnálni (pl. néhányan leselejtezik a gépüket és újat vesznek helyette), vagy pedig lassú növekedés és ciklikus gyorsulás-lassulás következik be (ezt pedig a fogyasztói szokások változásával lehet párhuzamba állítani).

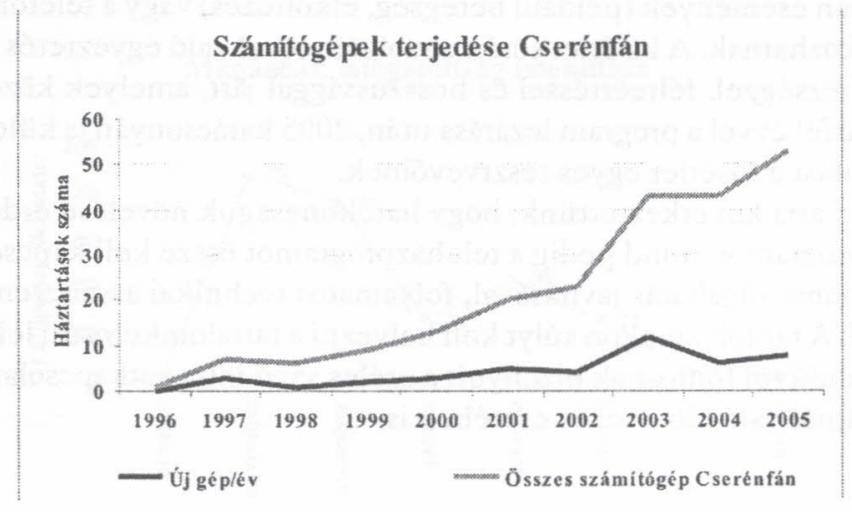

Forrás: Saját adatgyưjtés: Cserénfa, 2003-2005. 
Bár a kísérlet elején tapasztalható egy kiugrás, a kísérlet végén stagnálás következett be. A terjedés az $\mathrm{S}$ görbe alsó szakaszában tart, a trend némi kiugrás után követni látszik az eredeti irányt. Következésképpen nem lehet igazolni, hogy a számítógépek terjedésére érdemben hatott a kísérlet, mivel nem fedezhető fel különbség a kísérleti szakasz elótti és a kísérleti szakasz utáni növekedésben.

Az internet terjedése esetében már inkább gyanakodhatunk valamiféle hatásra. A résztvevôk egyötöde megtartotta az internet-elöfizetést. Továbbá több résztvevő is jelezte, hogy a kábeltévé bevezetése után szeretne az internetszolgáltatásra is előfizetni. Ez, miként az interjúk során kiderült, éppen a követéses vizsgálat idốpontjában vált esedékessé. Egy kaposvári cég olyan feltétellel vállalta a széles sávú internetkapcsolat létesítésére is alkalmas hálózat egy éven belüli kiépítését, ha azt legalább ötven család igényli. Voltak, akiket kifejezetten az internetes csatlakozás lehetôsége motivált, és volt olyan is, aki azért írta alá a szerzôdéskötési szándéknyilatkozatot, mert nem akart a kezdeményezés kerékkötôje lenni. Noha a faluban gyakran panaszkodtak a befelé fordulásra, rossz közérzetre és hangulatra, s noha az akció idején a helyi közéletben vita is támadt, az eset világosan jelzi, hogy vannak ilyen irányú igények, és ezek kielégítése érdekében a résztvevók kritikus tömege hajlandó a kooperációra.

\subsection{Van-e a teleház és a számítógépes kihelyezés között kölcsönhatás?}

Vizsgálatunk során úgy tứnt, hogy a magánházakhoz kihelyezett gépek és internetvonalak, illetve a teleház használata kiváltja egymást: a kihelyezés időszakában a falubeliek inkább egymáshoz jártak át számítógépezni, mintsem a teleházba, ami a költségek miatt érthetô is.

A 2003 és 2005 közötti időszakban a teleházban a következő három tényezốt mérték: hányszor vették igénybe a teleházat az adott hónapban (a látogatási alkalmak száma), az internethasználat ideje (perc) és a géphasználat ideje (perc). Az ábrákon látható, hogy a teleház használata mindhárom indikátor szerint szezonális ingadozást mutat. A kezdeti érdeklődés után a nyári hónapokban általában megnő a látogatók száma, ami azzal áll összefüggésben, hogy a teleházat jórészt fiatalok használják. 2005-ben azonban az érdeklő́dés csúcsidóben is csökkeni látszik.

Kísérletünk a téli-tavaszi holtszezonra esett, így a tendencia valójában nem függ számottevően a számítógépek és az internet kihelyezésétól. Megállapítható ugyanis, hogy ezekben a hónapokban egy évvel késóbb is hasonlóan gyenge aktivitás volt tapasztalható a teleházban. Következésképpen nem lehet azt mondani, hogy a számítógépek kihelyezése lényegében megváltoztatta volna a teleház használatát. Ami számunkra a rövid távú vizsgálati eredmények összegzésekor közvetlen összefüggésnek tetszett, az valójában jelentôs részben egy szezonális hatás eredménye volt.

A teleház használatát két technikai tényező befolyásolja érdemben: a teleház ADSL-vonala, amelyet követéses vizsgálatunk elốtt két héttel kötöttek be, valamint a jövő évben bevezetendő kábeltévés szolgáltatás, melynek segítségével a magánházak széles sávú internetcsatlakozást létesíthetnek. 

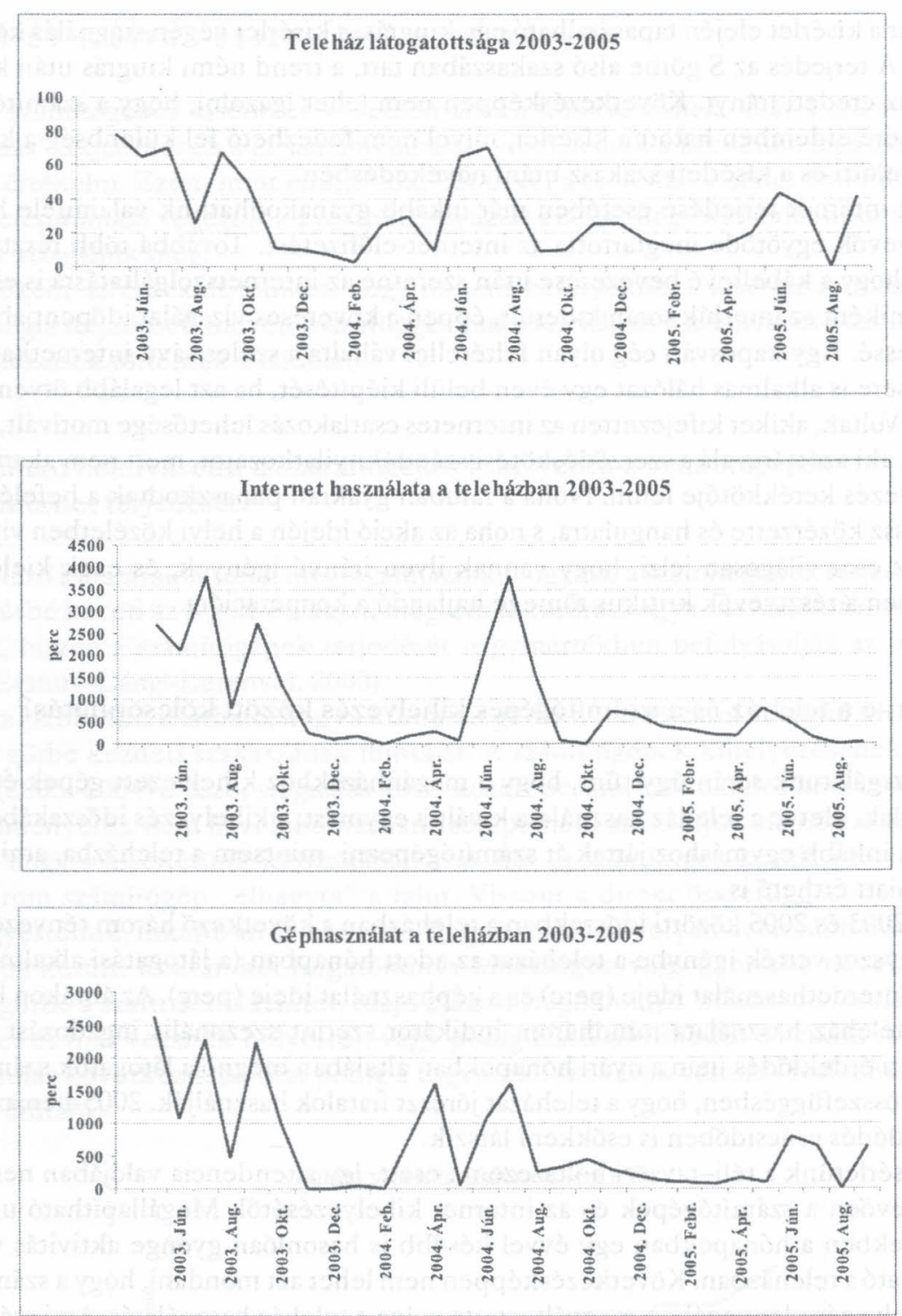

Forrás: A teleház által vezetett statisztika: Cserénfa, 2003-2004.

\subsection{Milyen változás tapasztalható a faluban?}

2005 októberében terepmunkánk során azt tapasztaltuk, hogy kitapinthatóvá vált egy konfliktus a falu vezetése és a lakosság egy része között. Interjúalanyaink arról számoltak be, hogy a konfliktus hátterében a fejlesztésekkel kapcsolatos elégedetlenség 
és személyi ellentétek állnak. A választások közeledtével az sem zárható ki, hogy mindez a helyi közéletben lecsapódó politikai erôpróba ürügyévé válik. Korábbi vizsgálatunk során is panaszkodtak interjúalanyaink olyan jelenségekre, amelyek az elidegenedés és az individualizmus fogalmaival ragadhatók meg, azonban ennek ellenére a közösségi gyarapodás és rendezôdés jeleivel is találkoztunk. A kontrolltelepülésként kezelt, ugyanabban a kistérségben található Szilvásszentmárton közösségi élete az előző választások során kiéleződött konfliktusokat követően gyakorlatilag megbénult. Ott nem csupán magárahagyatottságról és nemtörődömségról, hanem rosszindulatról és haragról szóltak a beszámolók. Szilvásszentmártonban kevés az új építésú ház, és a vizsgálat idején a házak fele vakolatlan volt. Cserénfán a lakosság lassan gyarapszik, épülnek új porták, mások kibővü̈lnek (interjúalanyaink egyharmada építkezett), s a házaknak csak a negyedrésze volt vakolatlan. Félő, hogy a konfliktusok kiéleződése visszavetheti azt a fejlődési folyamatot, ami egy bizalomteli légkör megteremtését szolgálta.

Mindez szúkebb vizsgálati kérdésünkkel, az információs technológia terjedésével csupán két vékony szálon függ össze. Az egyik az, hogy a helyi közösségi életnek a kocsma mellett gyakorlatilag az egyetlen színtere a teleház. Ha ez megosztja a közvéleményt, ha kritikák középpontjába kerül, akkor ezzel az együttmúködés és a közszolgáltatások egy fontos fóruma paralizálódhat.

A másik szál a kihelyezésekhez fúződik. A kihelyezéses kísérlet során tapasztaltunk negatív mellékhatásokat, így például internetfüggốséget, idóleges marginalizálódást és irigységet. Tapasztaltuk ugyanakkor a szolidaritás és a felelősségtudat felébredését is. A terepmunka, továbbá a résztvevókkel elkészített interjúk alapján azt láttuk, hogy a kihelyezés és a közélet között nem volt direkt kapcsolat, ám a kihelyezés összességében inkább pozitivan hatott a normákra és értékekre.

Mind a teleház, mind pedig a magánházakhoz való kihelyezés esetében figyelembe kell venni az egyénekre, illetve a közösségre gyakorolt hatást. Ebben a tekintetben a kihelyezés a tágabb lehetốségek miatt, a teleház pedig centrális helyzete miatt vetíti ki pozitív hatását a közösségre. Ugyanakkor a teleház és a kihelyezés is a hozzáférési esélyegyenlôtlenség, a társadalmi egyenlőtlenségek és a digitális szakadék miatt generálhat konfliktust a közösségben.

\section{Irodalom}

Eranus Eliza - Láng Sarolta - Letenyei László (2003): Személyi úton terjedő számítógép. In Kultúra és körösség, III/VII/4: 94-113.

Eranus Eliza - Letenyei László (2004): Teleház és/vagy magánház? In Lengyel György - Siklós Viktória (szerk.) (2004): A cserénfai kísérlet. Beszámoló egy aprófaluban lebonyolitott számítógépés internettelepités tapasztalatairól. Múhelytanulmányok. BKÁE Szociológia és Szociálpolitika Tanszék, 63-87.

Futó Péter (2003): Terepszemle és számítógép-kezelési előadás. Beszámoló a tapasztalatokról.

Füleki Dániel (2003): Beszámoló a számítógépes oktatás tapasztalatairól.

Láng Sarolta - Letenyei László - Siklós Viktória (2003): Információs technológia diffúzió: Információs technológia és szakismeretek terjedése a kaposvári kistérségben. Múhelytanulmány, BKÁE Információs technológiák és helyi társadalom címú kutatás. 
Lengyel György (szerk.) (2002): Információs technológia és szolgáltató közigazgatás. Budapest: BKÁE.

Lengyel György (szerk.) (2003): Információs technológia és életminőség. Budapest: BKÁE.

Lengyel György - Siklós Viktória (szerk.) (2004): A cserénfai kísérlet. Beszámoló egy aprófaluban lebonyolított számítógép- és internettelepítés tapasztalatairól. Múhelytanulmányok. BKÁE Szociológia és Szociálpolitika Tanszék.

Lengyel Gy. - Eranus E. - Füleki D. - Lőrincz L. - Siklós V. (2004): A cserénfai kísérlet. Jel-kép, 2004/2, 79-96.

Siklós Viktória (2004): Esettanulmány a cserénfai teleházról. In Lengyel György - Siklós Viktória (szerk.) (2004): A cserénfai kísérlet. Beszámoló egy aprófaluban lebonyolított számítógépés internettelepítés tapasztalatairól. Múhelytanulmányok. BKÁE 


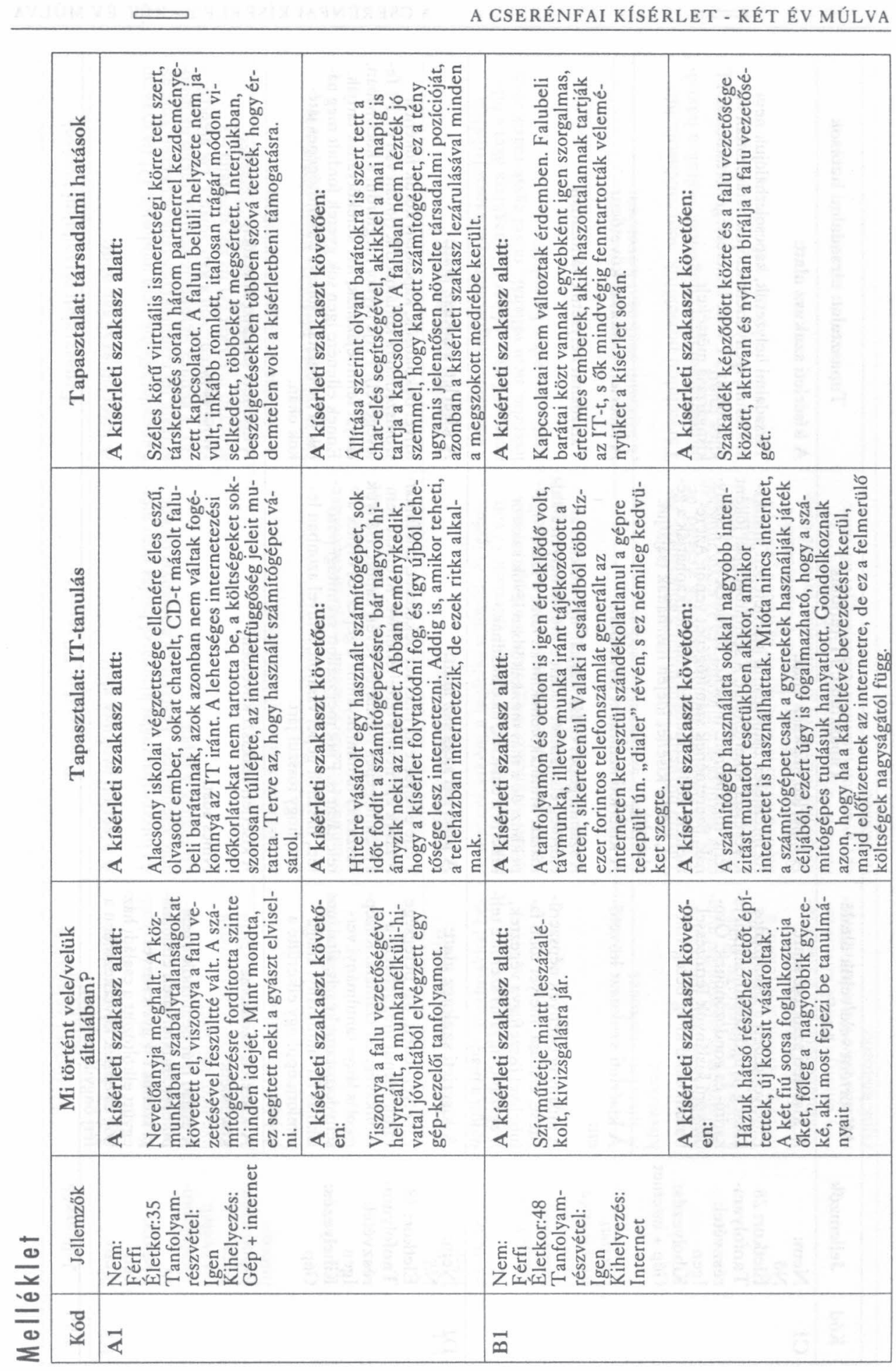




\begin{tabular}{|c|c|c|c|c|c|c|c|c|}
\hline 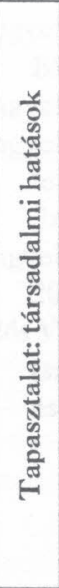 & 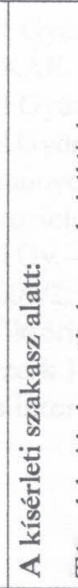 & 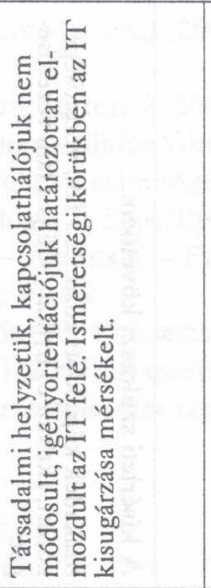 & 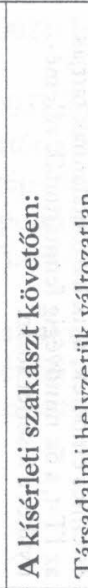 & 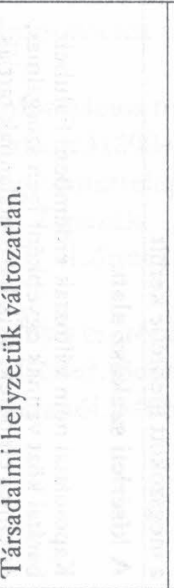 & & 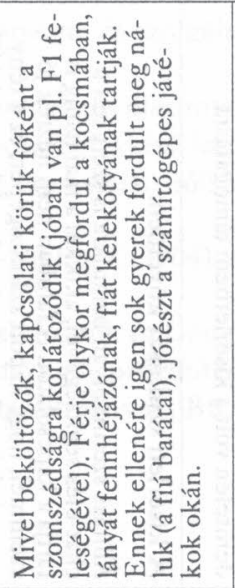 & 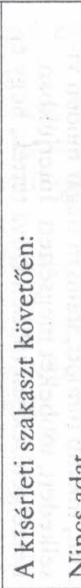 & \\
\hline 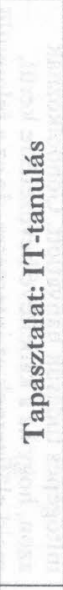 & $\mid \begin{array}{l} \\
\\
0\end{array}$ & 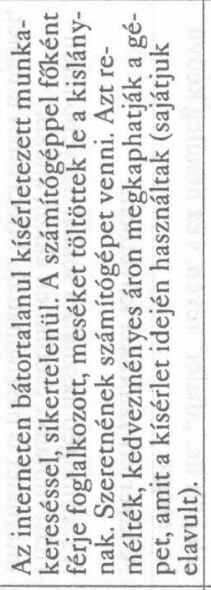 & 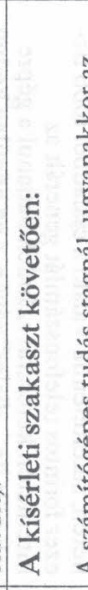 & 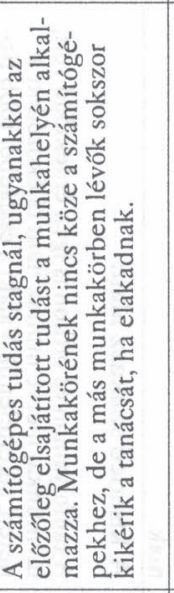 & 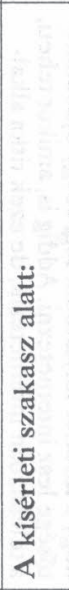 & 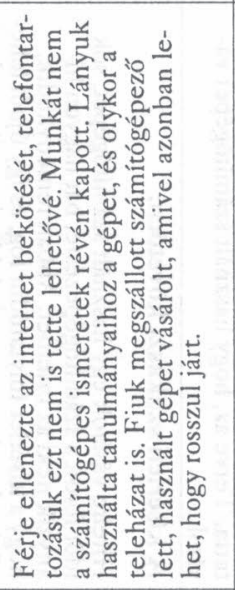 & 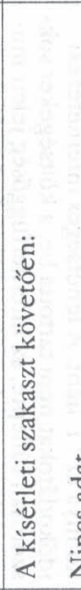 & 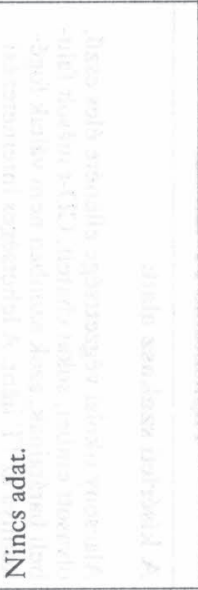 \\
\hline 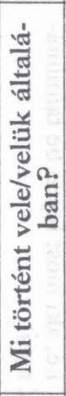 & 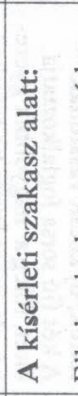 & 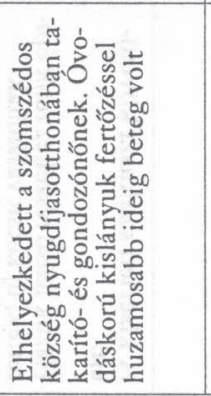 & 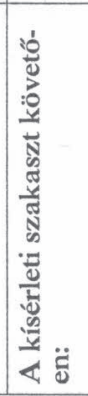 & 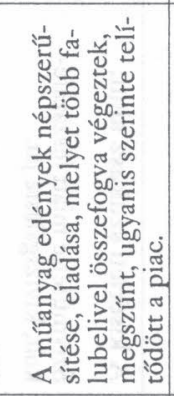 & 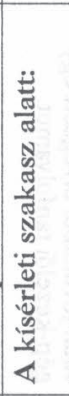 & 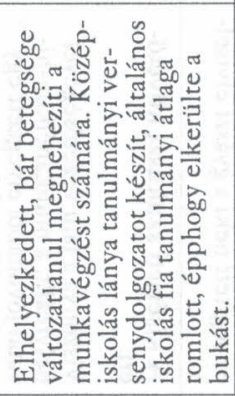 & 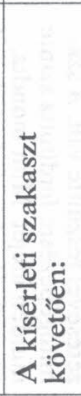 & 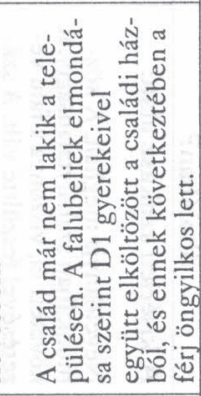 \\
\hline 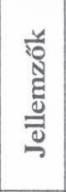 & & 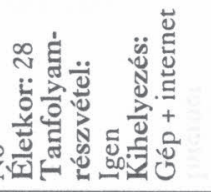 & & & & 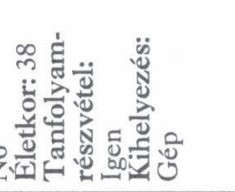 & & \\
\hline 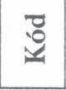 & 0 & & & & & & & \\
\hline
\end{tabular}




\begin{tabular}{|c|c|c|c|c|c|c|}
\hline 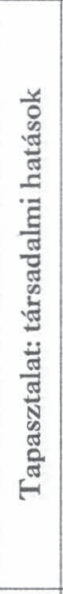 & 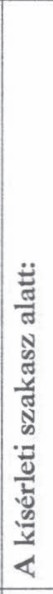 & 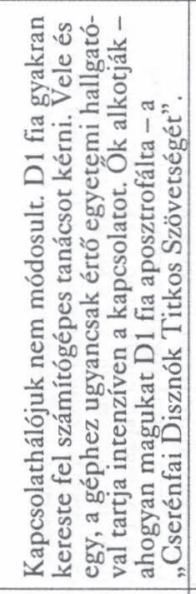 & 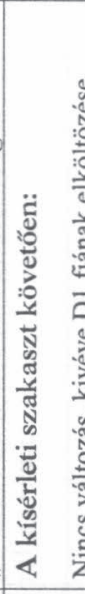 & 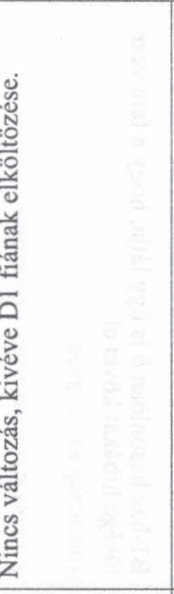 & 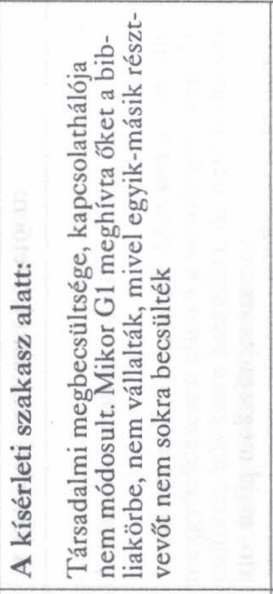 & 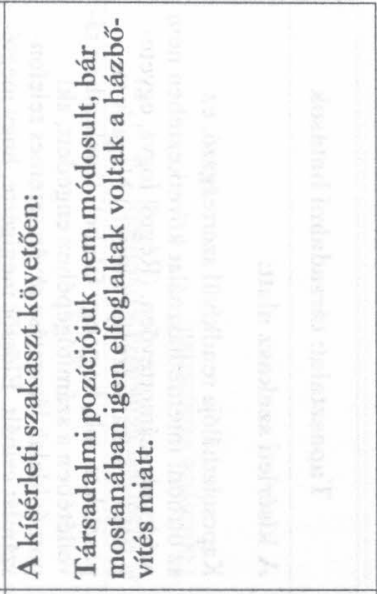 \\
\hline 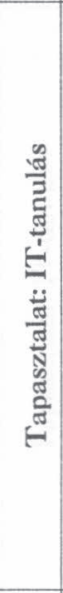 & 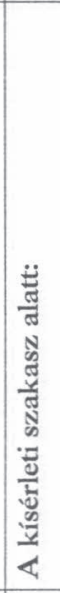 & 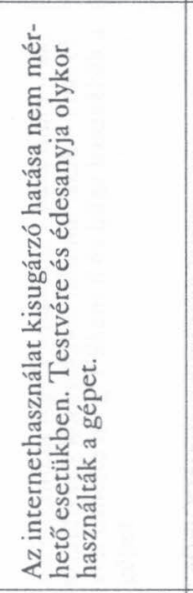 & 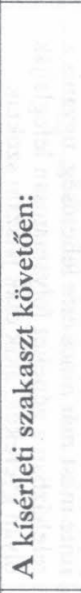 & 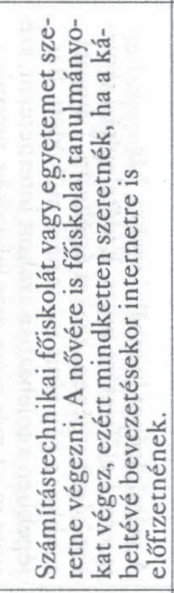 & 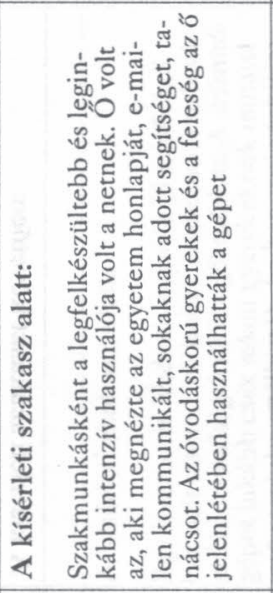 & 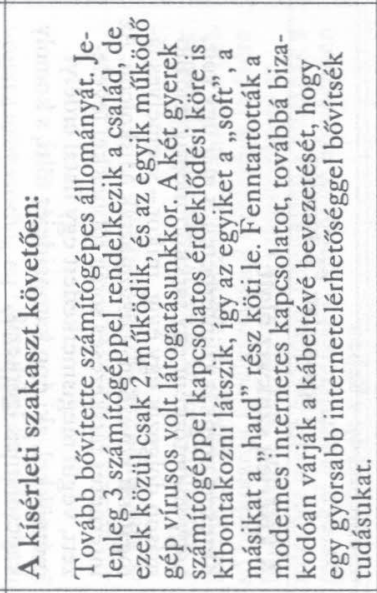 \\
\hline 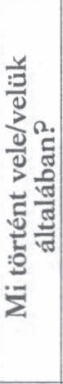 & 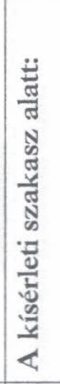 & 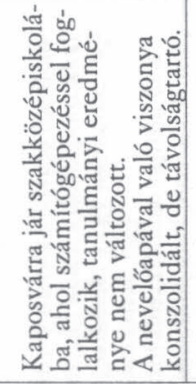 & 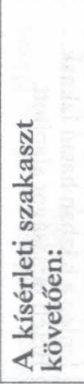 & 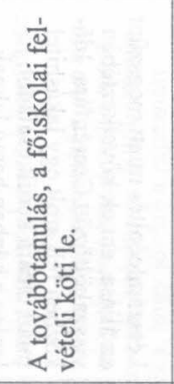 & 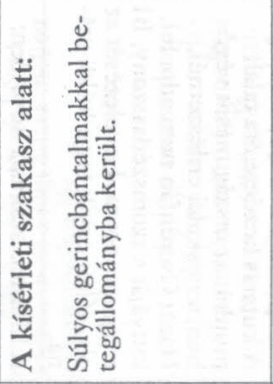 & 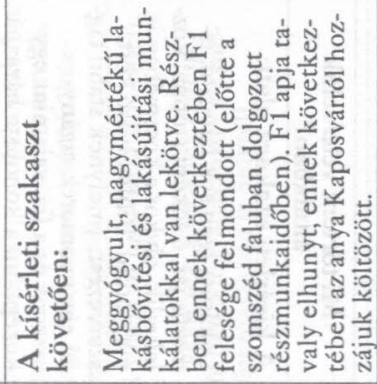 \\
\hline 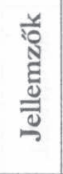 & & 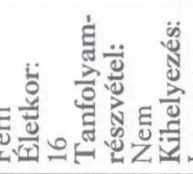 & & & 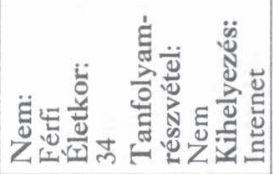 & \\
\hline$\vec{g}$ & (x) & & & & & \\
\hline
\end{tabular}




\begin{tabular}{|c|c|c|c|}
\hline 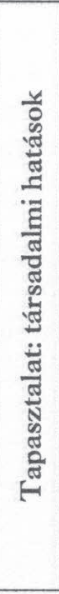 & 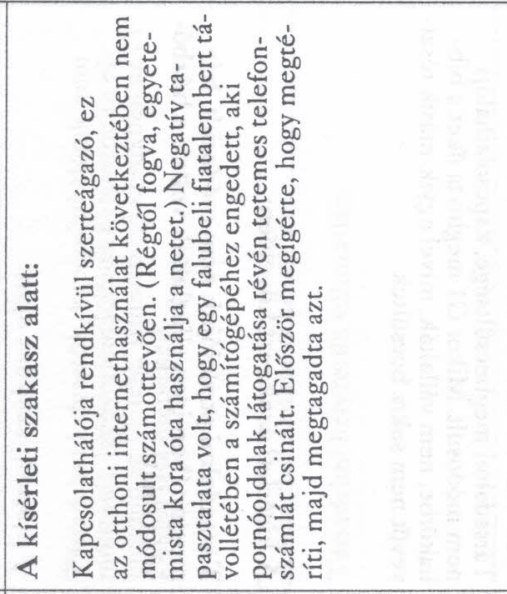 & 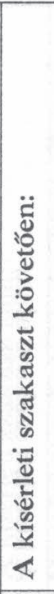 & 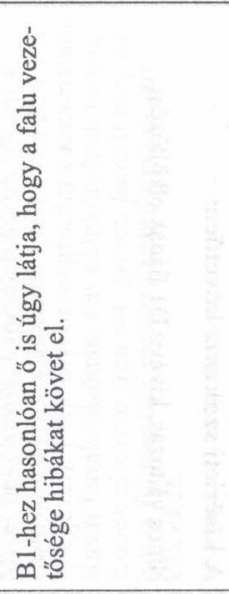 \\
\hline 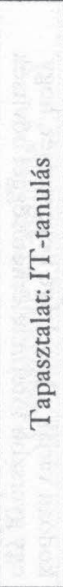 & 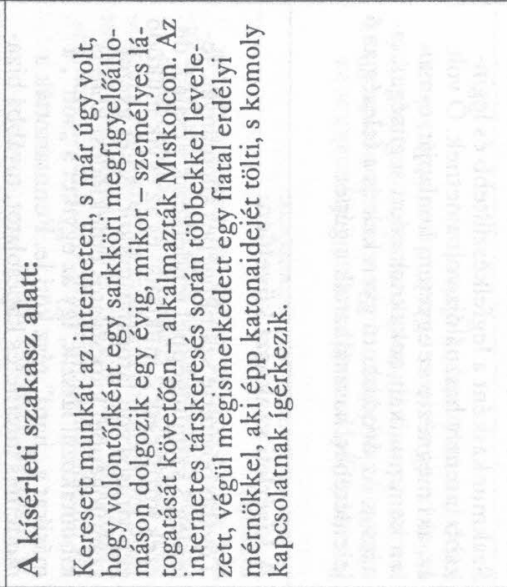 & 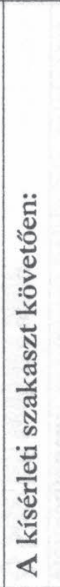 & 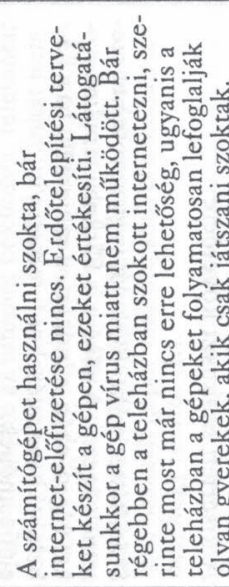 \\
\hline 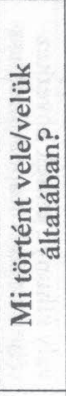 & 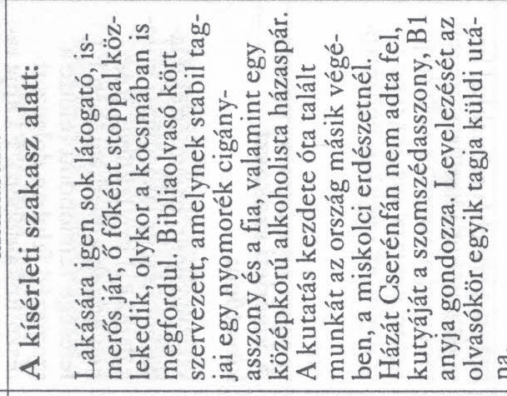 & 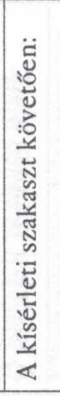 & 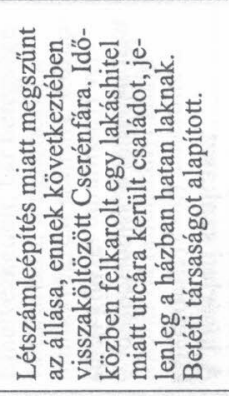 \\
\hline 造 & 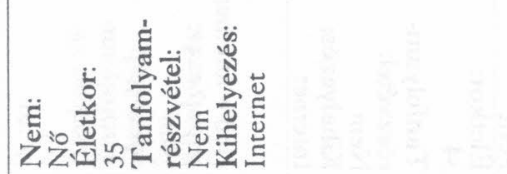 & & \\
\hline 苞 & & & \\
\hline
\end{tabular}




\begin{tabular}{|c|c|c|c|c|c|c|c|c|}
\hline 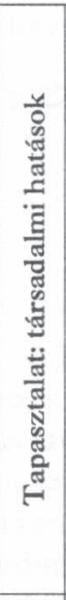 & 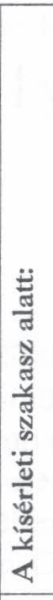 & 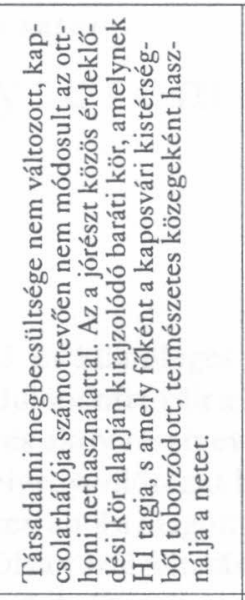 & 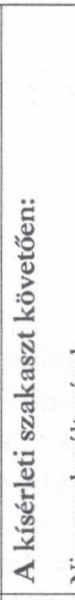 & 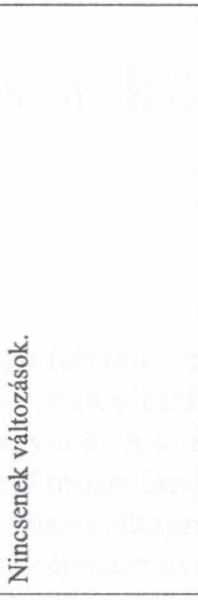 & 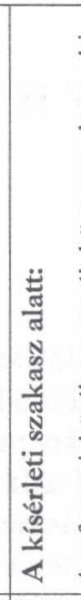 & 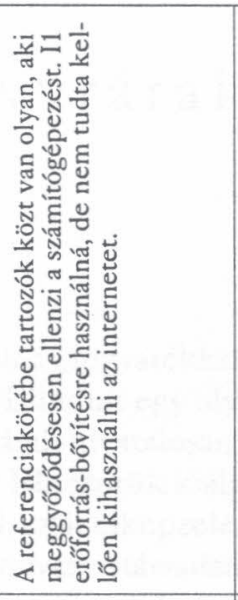 & 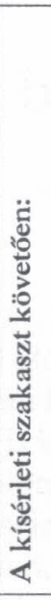 & 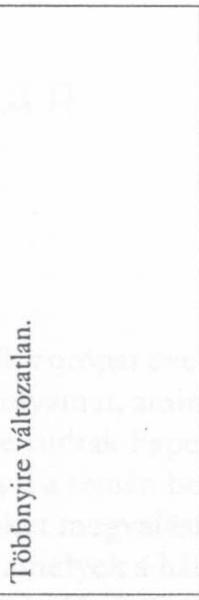 \\
\hline 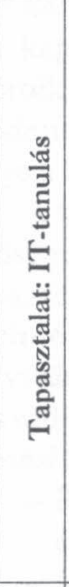 & 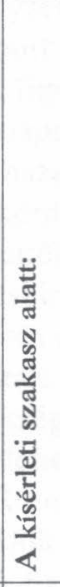 & 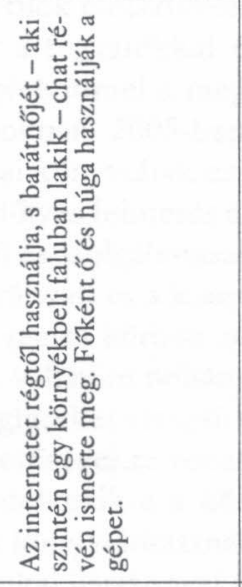 & 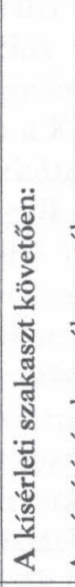 & 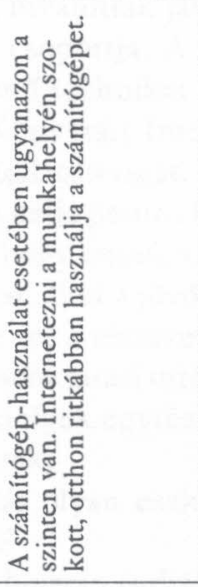 & 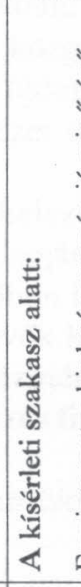 & 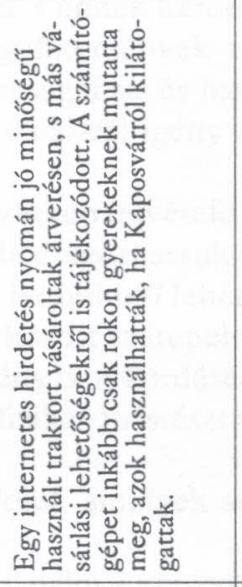 & 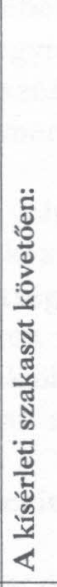 & 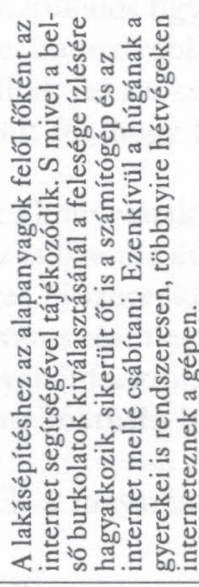 \\
\hline 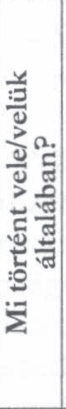 & 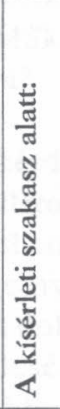 & 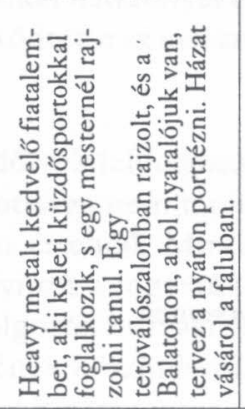 & 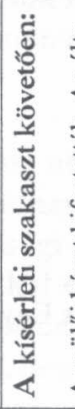 & 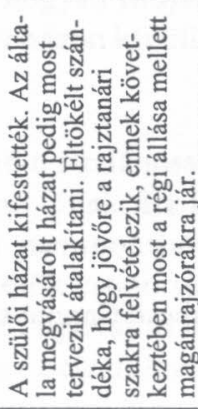 & 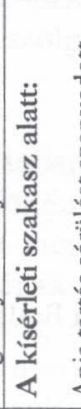 & 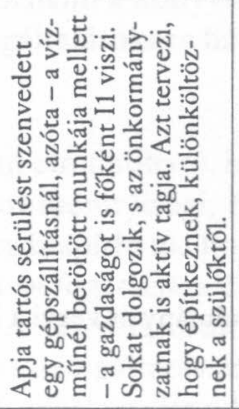 & 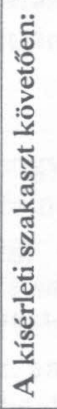 & 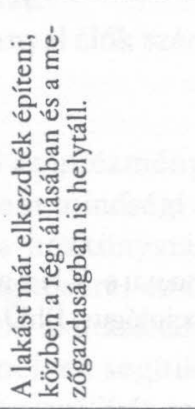 \\
\hline 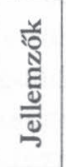 & & 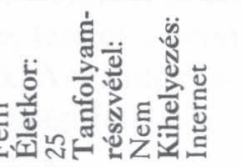 & & & & 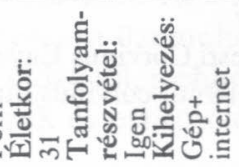 & & \\
\hline 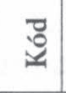 & & & & & & & & \\
\hline
\end{tabular}

